\title{
A Method for Determining Optimum Harvesting Date of 2-B Bushy Pigeon Pea'
}

\author{
José R. Benero, Horacio Ortiz, Edwin Acevedo and Angel J. \\ Rodríguez $z^{2}$ \\ ABSTRACT
}

Standard time-yield curves which fit closely the observed data were worked out using equation $Y=\frac{A}{1+B(X-C)^{2}}$ Optimum harvesting dates for 2-B Bushy pigeon pea can be determined from the percentage of canning size peas of samples drawn using the standard time-yield curves or directly from tables prepared from them. Canned samples collected at the optimum harvesting date according to the curves were always of an A or B quality grade.

\section{INTRODUCTION}

Pigeon peas (Cajanus cajan $\mathrm{L}$ ) is an important local agricultural product from the economic and nutritional standpoints. Traditionally harvesting has been done by hand in successive steps in which pickers harvest the mature pods only. Sánchez-Nieva et al. $(6,7)$ have demonstrated that good quality canned pigeon peas (A or B grade) and a good income can be obtained by a single picking. Mechanical harvesting of pigeon peas has been delayed by two major factors: the plant height and the fruit bearing characteristics of the known varieties. Recently a new pigeon pea experimental line known as 2-B Bushy was developed at the Isabela Substation. This pea line seems to have the appropriate height and a definite fruit bearing pattern which are essential for mechanical harvesting. However, the mechanical harvesting of pigeon peas presents the problem of determining the optimum date for harvesting; that is, the date at which the optimum yield of good quality produce can be obtained. Although studies of this type have been conducted on garden peas (4) and beans (5) no such work has been reported on pigeon peas. This paper discusses the utilization of a standard curve and/or tables prepared from it for the determination of the optimum harvesting dates of 2-B Bushy pigeon peas.

${ }^{1}$ Manuscript submitted to Editorial Board October 22, 1979.

${ }^{2}$ Associate Chemist, Research Assistant, Associate Agronomist and Chemical Engineer, respectively, Agricultural Experiment Station, Mayagüez Campus, University of Puerto Rico, Río Piedras, P.R.

The authors thank Mr. Dámaso Quiñones of the United State Department of Agriculture for the grading of the canned samples.

Mr. Mariano Antoni and Dr. Bernardo G. Capó of the Statistics Department of the Agricultural Experiment Station advised and arranged for the analysis and interpretation of the data. 


\section{MATERIALS AND METHODS}

One-acre plots of 2-B Bushy pigeon peas were planted at the Isabela and Fortuna Substations during the years 1976 to 1978. Randomized samples were collected at regular intervals starting about 15 days after peak flowering and from there on until the samples consisted mainly of over-mature and dry peas. On each sampling date two samples were collected simultaneously, one from 15 plants and another from 150 plants. During sampling, all pods, irrespective of the stage of maturity, including very small and young ones, were picked. The 15-plant sample was hand shelled, including the very small pods. The shelled peas were weighed and classified with staggered round-hole sieves of the sizes $9 / 32^{\prime \prime}$ to $12 /$ $32^{\prime \prime}$. Canning size pea yields (peas 10/32" or larger) were calculated as both percent on weight and percent on count basis. Canning size pea yield was determined either by adding up the weight of the peas 10/32" or larger or by multiplying the percent (weight basis) of canning size peas by the weight of all the shelled peas. The sample from the 150 plants was processed and canned by the method described by Sánchez et al. (8). The canned samples were graded according to USDA standards for canned green pigeon peas. Standard time-yield curves were calculated by fitting equations of the $\mathrm{Y}=\frac{\mathrm{A}}{1+\mathrm{B}(\mathrm{X}-\mathrm{C})^{2}}$ type.

\section{RESULTS AND DISCUSSION}

Equation $\mathrm{Y}=\frac{\mathrm{A}}{1+\mathrm{B}(\mathrm{X}-\mathrm{C})^{2}}$ is known as the fertilizer-yield equation $(1,2,3)$. In this equation $A, B$ and $C$ are three parameters. When applied to a time-yield relation, as is the case of our studies with pigeon peas, $A$ represents the maximum canning size peas yield obtainable at the optimum harvesting date; $C$ represents the optimum time interval, after the first sample was picked, at which the maximum yield occurs; $B$ may be assumed to be an index of the variability of the crop yield as the time interval differs from the optimum harvesting date; $\mathrm{X}$ represents any time interval, after the first sample was picked; and $\mathrm{Y}$ is the yield at any time $\mathrm{X}$.

The test for fitness revealed that equation $\mathrm{Y}=\frac{\mathrm{A}}{1+\mathrm{B}(\mathrm{X}-\mathrm{C})^{2}}$ explains very well the time-yield relations for 2 -B Bushy pigeon pea. Table 1 shows the coefficients of determination and the correlation coefficients calculated for each experiment separately and for all experiments together. They all demonstrate a very high correlation, that is, at the $1 \%$ level of significance. The estimated values of parameters $A, B$ and $C$, calculated using all the data of localities data with the yields expressed as 
percent on a weight bases were: $A=96.15, B=0.0055$ and $C=22.98$. The curve with these values constitutes the first proposed standard curve for harvesting, fig. 1 . The maximum yield $(96.15 \%)$ occurred at the point corresponding to 22.98 days. For any difference in time from 22.98 days there will be a corresponding point in the curve indicating the percent of

TABLE 1.-Fits of curves traced with equation $\mathrm{Y}=\frac{\mathrm{A}}{1+\mathrm{B}(\mathrm{X}-\mathrm{C})^{2}}$ to explain the time-yield relation of 2-B Bushy pigeon pea

\begin{tabular}{|c|c|c|c|c|c|}
\hline \multirow{2}{*}{$\begin{array}{l}\text { Locality } \\
\text { and year }\end{array}$} & \multirow{2}{*}{$\begin{array}{l}\text { Degrees } \\
\text { of } \\
\text { freedom }\end{array}$} & \multicolumn{2}{|c|}{ Coefficient of determination } & \multicolumn{2}{|c|}{ Correlation coefficients } \\
\hline & & $W^{1}$ & $\mathrm{C}^{1}$ & W & C \\
\hline Isabela 1976 & 7 & 0.8136 & 0.9251 & $0.9019 * * 2$ & $0.9618 * *$ \\
\hline Isabela 1977 & 10 & 0.7611 & 0.9109 & $0.8724 * *$ & $0.9544^{* *}$ \\
\hline Isabela 1978 & 11 & 0.8313 & 0.9593 & $0.9117^{* *}$ & $0.9794^{* *}$ \\
\hline Fortuna 1,977 & 7 & 0.8980 & 0.8365 & $0.9476^{* *}$ & $0.9146^{* *}$ \\
\hline Fortuna 1978 & 6 & 0.8905 & 0.9216 & $0.9436^{* *}$ & $0.9600 * *$ \\
\hline $\begin{array}{l}\text { All localities, all } \\
\text { years }\end{array}$ & 53 & 0.6874 & 0.6181 & $0.8297^{* *}$ & $0.7877^{* *}$ \\
\hline
\end{tabular}

' $\mathrm{W}=$ coefficients calculated when yields were expressed as percent on a weight basis. $\mathrm{C}$ $=$ coefficients calculated when yields were expressed as percent on a count basis.

${ }^{2}$ Significant at the $1 \%$ probability level.

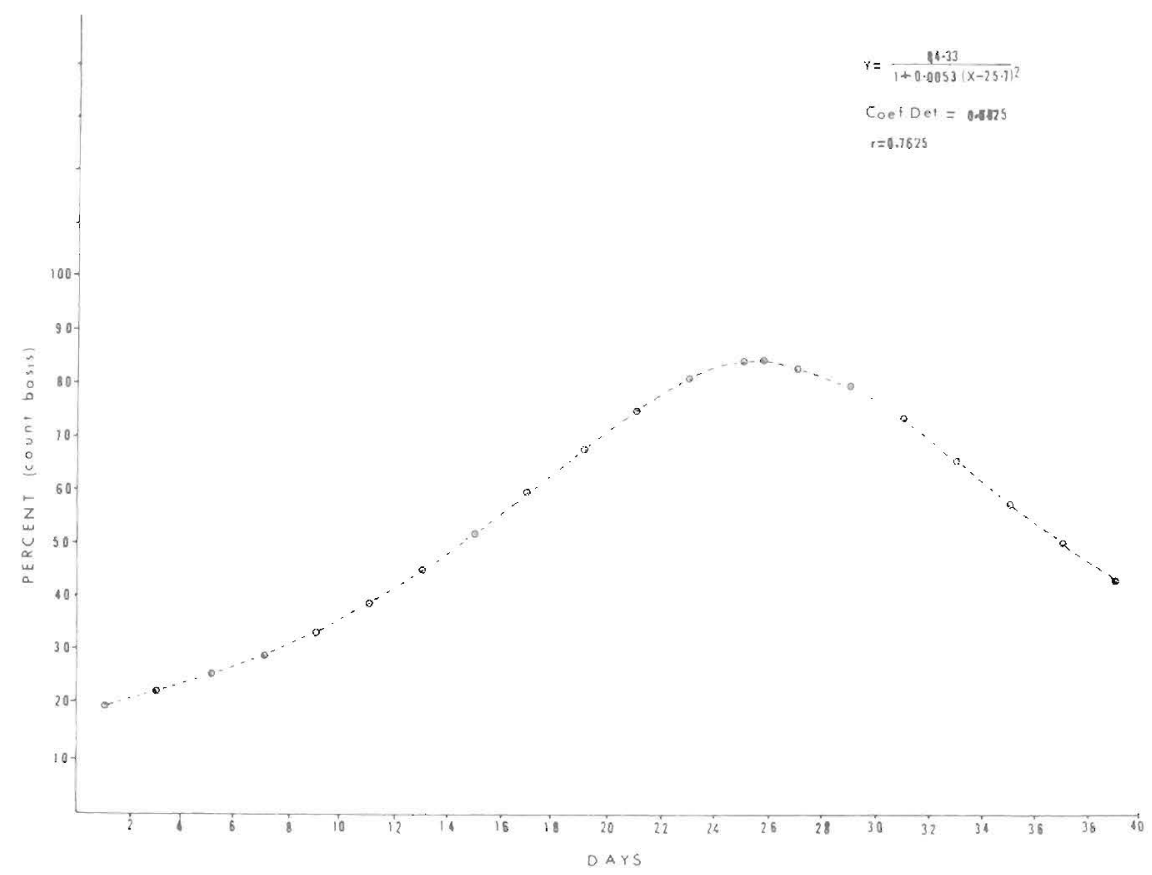

FIG. 1.-Percentage of canning size peas (count basis) vs. time interval (days). 
canning size peas and viceversa; therefore, by finding out the percent of canning size peas in a sampled drawn from a planting and determining from the curve how many days it will take to reach the maximum canning size yield, the optimum harvesting date can be determined. To simplify the procedure for the estimation of the optimum harvesting date a percent-time table has been worked out, as follows.

\section{Percent (weight basis) of can-} ning size peas

96.2

95.6

94.1

91.7

88.4

84.2

80.3

75.8

71.2

66.6

62.0

57.8

53.7

49.9

46.3

43.0

40.0

37.2

34.6

32.2

30.1

28.1

26.3
Days to reach optimum harvesting date

0
1
2
3
4
5
6
7
8
9
9
10
11
12
13
14
15
16
17
18
19
20
21
22

The estimated values of parameters $A, B$ and $C$ of equation $\mathrm{Y}=$ A $\frac{\mathrm{A}}{\mathrm{I}+\mathrm{B}(\mathrm{X}-\mathrm{C})^{2}}$ calculated using data from all localities with the yields expressed as percent on a count basis are: $A=84.33, B=0.0053$ and $C$ $=25.70$. The graph traced with these values constitutes the second standard curve proposed for harvesting, (fig. 2). This curves also can be used to determine the optimum harvesting date of the plantations in the same way as previously described. The following tabulation shows how to calculate the days off the optimum harvesting date.

Percent (count basis) of canning size peas

84.3

84.1
Days to reach optimum harvesting date 


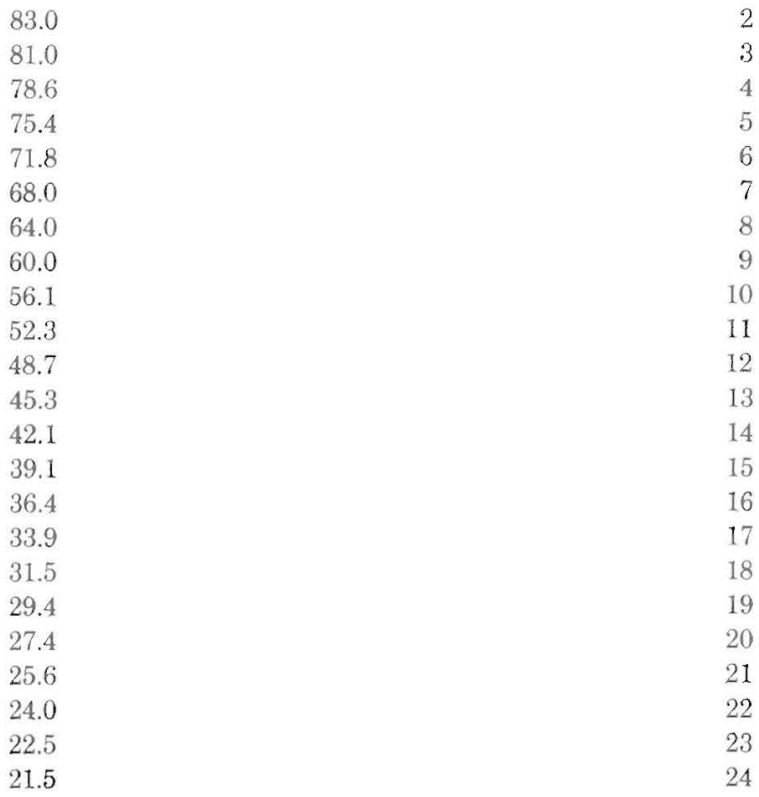

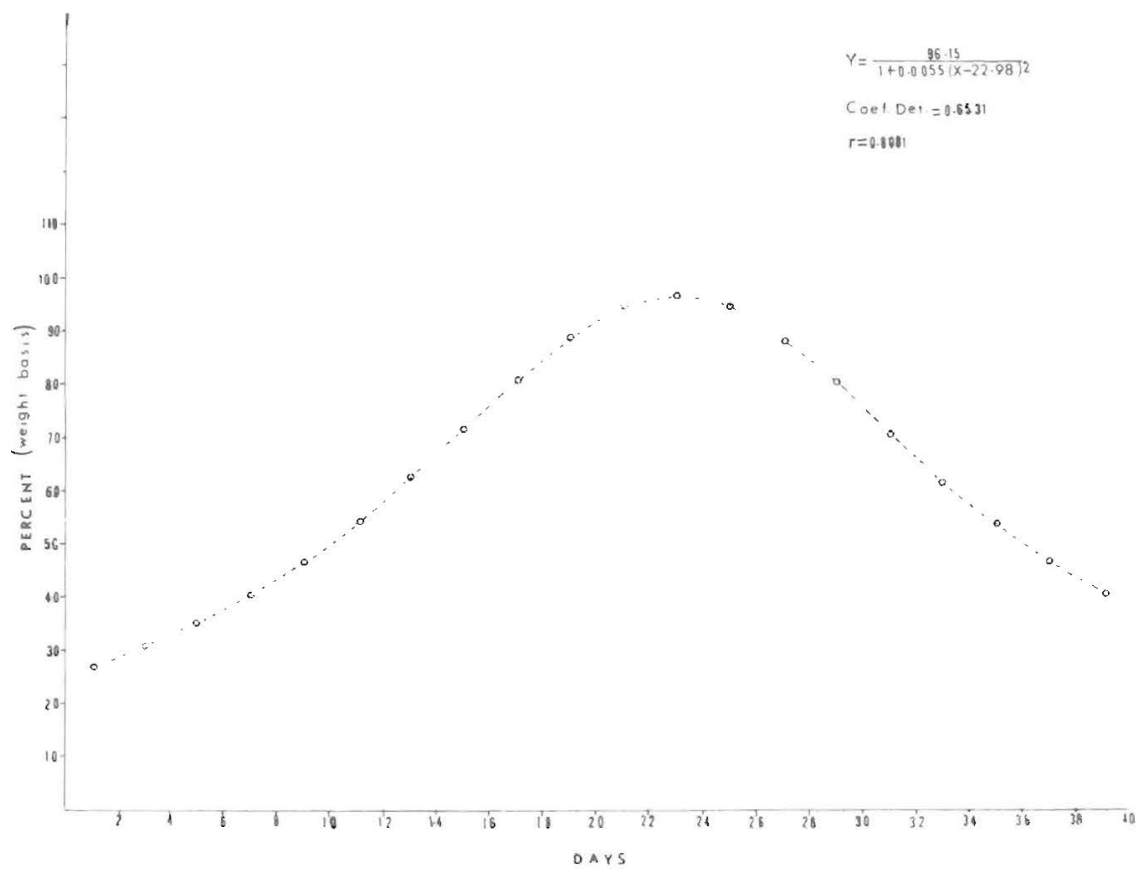

FIG. 2.-Percentage of canning size peas (weight basis) vs, time interval (days). 
The percentages of canning size peas, designated as yields, increased to a maximum and then decreased as the plants matured. At the same time, the weight of the samples from the 15 plants increased up to a maximum and then decreased. If we multiply the percentage of canning size peas by the weight of the shelled peas from a sample, we get the weight of all the canning size peas of the sample, designated as canning size pea yield.Maximum canning size pea yields seldom coincide with the maximum canning size pea yields as here designated; usually they come later. This is due to the fact that even with this 2-B Bushy pea line which is a determinate cultivar not all flowers, and of course not all peas, come out at the same time in the same plant or in all the plants. In the determination of the optimum harvesting date the quality of the produce that will be obtained has to be considered. Table 2 shows how the canning

TABLE 2.-Maximum canning size pea yields, time intervals at which they occurred and canning quality associated with them.

\begin{tabular}{|c|c|c|c|c|c|c|c|c|c|}
\hline \multirow{2}{*}{$\begin{array}{l}\text { Locality } \\
\text { and } \\
\text { year }\end{array}$} & \multicolumn{3}{|c|}{ Days $^{1}$} & \multicolumn{3}{|c|}{ Grade } & \multicolumn{3}{|c|}{ Yields } \\
\hline & $\mathrm{W}^{2}$ & $\mathrm{C}^{2}$ & $\mathrm{P}^{3}$ & W & $\mathrm{C}$ & $\mathrm{P}$ & W & C & $\mathrm{P}$ \\
\hline Fortuna 1977 & 21 & 21 & 28 & B & $\mathrm{B}$ & SSTD $^{4}$ & 80.6 & 65.5 & 933.0 \\
\hline Fortuna 1978 & 19 & 19 & 19 & A & A & A & 77.2 & 67.2 & $1,170.3$ \\
\hline Isabela 1976 & 21 & 21 & 24 & A & $\mathrm{A}$ & A & 88.2 & 76.7 & 767.8 \\
\hline Isabela 1977 & 18 & 32 & 32 & $B$ & $\mathrm{C}$ & C & 80.8 & 58.6 & 476.1 \\
\hline Isabela 1978 & 26 & 26 & 33 & B & B & SSTD & 81.5 & 65.5 & $1,434.4$ \\
\hline
\end{tabular}

${ }^{1}$ Time interval in days after first sample was picked at which the maximum yields occurred.

${ }^{2} \mathrm{~W}=$ percent weight basis. $\mathrm{C}=$ percent count basis.

${ }^{3} \mathrm{P}=$ production (percent weight basis $\times$ total grains weight in grams of 15 plants).

${ }^{4}$ Substandard.

quality of peas harvested at the peak of the yield and at the peak of the production stages varied, as the time interval at which they were produced varied. It can be seen that when the maximum yields (weight basis) came within a range of 18 to 26 days or within the range of 19 to 26 days (count basis) the canning quality was always either A or B grade.Beyond the upper limits of the ranges above established only $\mathrm{C}$ or SSTD (substandard) grades were obtained. The time intervals of 20.6 and 25.7 days corresponding to the peak points of the proposed harvesting curves lie within the above mentioned ranges respectively. Yield beyond the 28th day were of either a C or SSTD grade. Harvesting at the maximum production stage may render a substandard produce which is not marketable. Therefore, it may be concluded that by harvesting at the peak points of the proposed harvesting curves good yields and a good quality produce will be obtained. 
RESUMEN

Se calcularon curvas tipicas de tiempo y rendimiento usando ecuaciones del tipo $Y=\frac{A}{1+B(X-C)^{2}}$ que se ajustan muy bien a los datos observados. Con las curvas etipicas de tiempo y rendimiento o directa mente de tablas preparadas de las mismas se pueden deteriminar las fechas óptimas para cosechar las plantaciones de gandul de la cultivar 2-B Bushy a partir del porcientaje de semillas de tamaños propios para enlatar de muestras tomadas de las plantaciones. La calidad de las muestras enlatadas, tomadas en las fechas óptimas de recolección según las curvas fueron siempre de buena calidad: A o B.

\section{LITERATURE CITED}

I. Capó, B. G., 1965. A new fertilizer-yield equation, 12th Cong. Int. Soc. Sugarcane Technol., p. 380-9, San Juan, P.R.

2. _. 1967, Additional evidence on the applicability of the new fertilizer-yield relation, J. Agri. Univ. P.R., 51, (3): 97-120.

3. Mariota-Trias, F. and Capó, B.G., 1972. Applicability of the fertilizer-yield equation to production of sugar per acre in Puerto Rico, J. Agri. Univ. P.R., 56, (3): 193-200.

4. Makee, H.S., Robertson, R.N. and Lee, J.B., 1955. Physiology of Pea Fruits. I The Developing Fruit, Aust. J. Biol. Sci. 8: 137-63

5. Rodrigo, M., Navarro, A., Durán, L., Vayá, J. L. y Safón, J., 1977. Aptitud de índices de madurez de judias verdes para determinar el momento óptimo de la recolección mecánica, Inst. Agroquím. Technol. Alim., ATA, 17, (2).

6. Sánchez-Nieva, F., Benero, J., González, M.A. and Colom-Covas, G. 1963. Variación en la madurez del gandur durante el período de la cosecha, Esta. Exp. Agrí. Univ. P.R. Bol. 170.

7. and Colom-Covas, G., 1964. Ventajas para el agricultor de cosechar las vainas de gandures de una sola vez, Esta. Exp. Agrí. Univ. P.R. Bol. 181.

8. Rodríguez, A.J. and Benero, J.R., 1961. Improved methods of canning pigeon peas, Agri. Exp. Stn. Univ. P.R. Bul. 157. 